\title{
DIAGNOSIS AND MANAGEMENT PROTOCOL OF LINGUAL THYROID
}

Venkata Subba Rao Bhanumathi' ${ }^{1}$ Syamji Venkata Ramana Rao ${ }^{2}$

${ }^{1}$ Associate Professor, Department of Surgery, Osmania Medical College, Hyderabad.

2 Professor, Department of ENT, Osmania Medical College, Hyderabad.

\section{ABSTRACT}

Lingual thyroid is one of the commonest manifestations of ectopic thyroid tissue. Ectopic thyroid refers to thyroid tissue present in locations other than the anterior part of neck between second and fourth tracheal rings. Lingual thyroid presents with symptoms of dysphagia and sometimes stridor depending on the size of the swelling.

\section{KEYWORDS}

Ectopic Thyroid Tissue, Lingual Thyroid, Dysphagia, Dyspnea.

HOW TO CITE THIS ARTICLE: Bhanumathi VSR, Rao SVR. Diagnosis and management protocol of lingual thyroid. J Evolution Med Dent Sci 2016;5(1):100-102, DOI: 10.14260/jemds/2016/23

\section{INTRODUCTION}

Lingual thyroid is commonest type of ectopic thyroid tissue accounting for $90 \%$ of cases. Other regions of ectopic thyroid tissue are sub-lingual at the level of hyoid bone, submandibular, tracheal, lateral cervical, maxillary, palatine tonsils, esophageal stomach, pancreas and intestines.

\section{CASE REPORT}

An 8-yr-old female presented to the department of surgery, Osmania Hospital with the swelling behind the tongue producing difficulty for swallowing. On protrusion of tongue a semi lobular swelling is seen attached to the base of tongue. The swelling is pinkish in colour and solid in consistency on distal examination. Patient is subjected to CT scan of the neck, which shows a soft tissue lobular swelling at the base of the tongue. USN neck showed similar findings. Thyroid profile showed elevated TSH. Technetium scan shows uptake of radioactive material only at the base of the tongue. No uptake was seen in the normal region of the neck indicating lingual thyroid is the only functioning thyroid tissue in the body. Patient is started on Levothyroxine sodium anhydrous BP 50 micrograms/day for a period of 6 months after which the size of lingual thyroid has reduced. The symptoms of difficulty of swallowing were relieved and the patient is continued on thyroid replacement therapy. The case is reported for its rarity and it is for discussion of its management protocol.

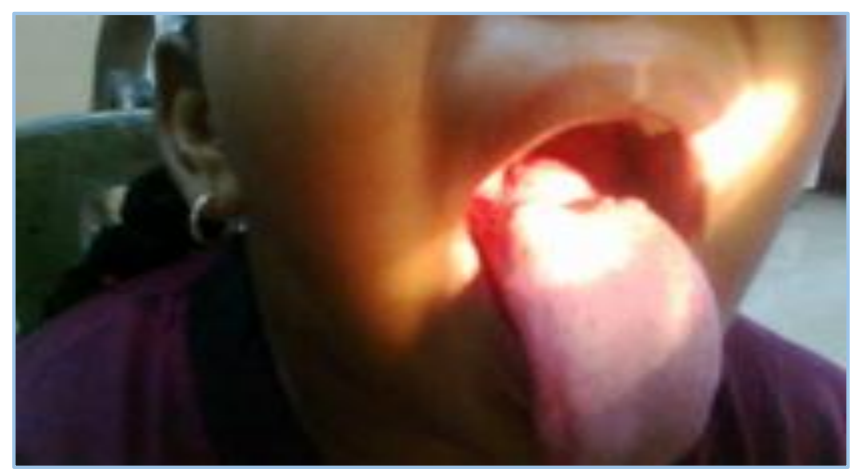

Fig. 1: Lingual thyroid visible on protrusion of tongue

Financial or Other, Competing Interest: None.

Submission 14-12-2015, Peer Review 15-12-2015,

Acceptance 30-12-2015, Published 04-01-2016.

Corresponding Author:

Dr. Venkata Subba Rao Bhanumathi,

8-53/2, North Kamalanagar,

Hyderabad-500062.

E-mail: dr.bhanumathirao@yahoo.com

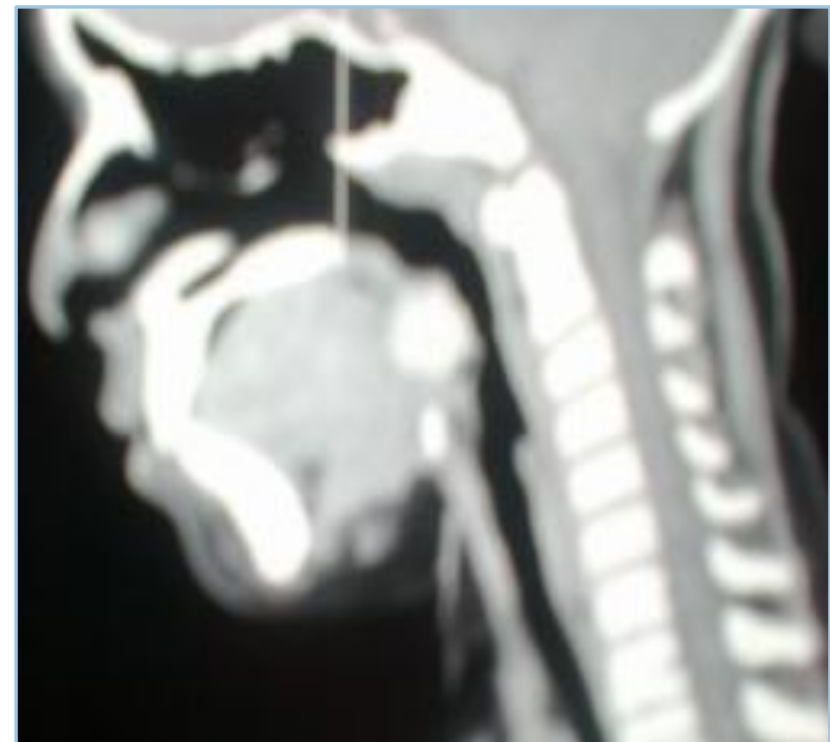

Fig. 2: CT scan showing soft tissue swelling at the base of the tongue

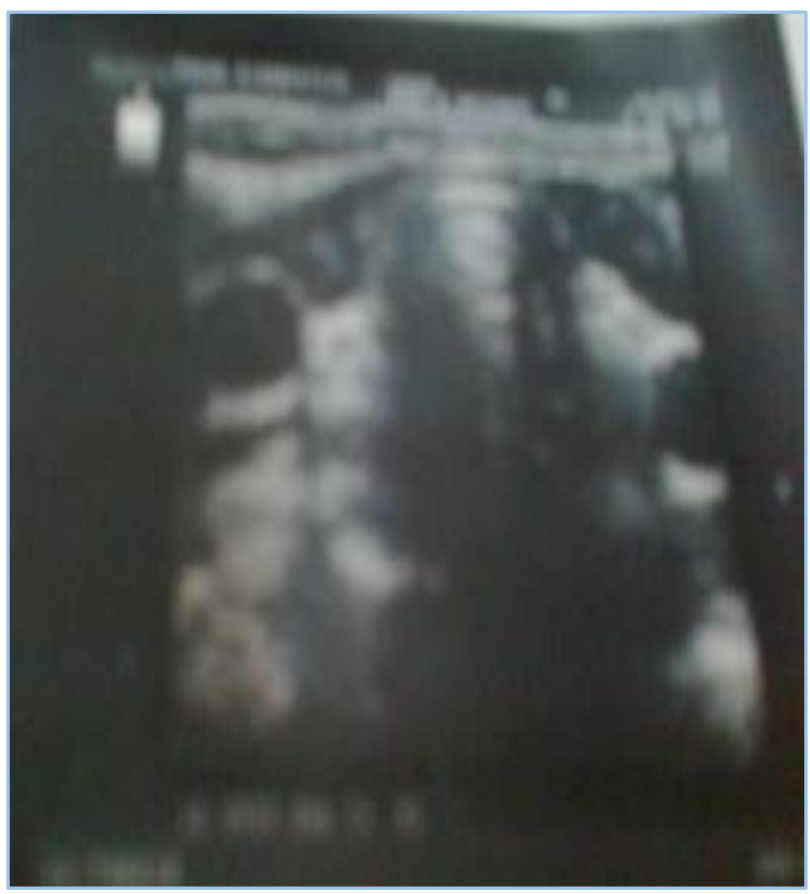

Fig. 3: Ultrasound showing absence of gland in the neck DOI:10.14260/jemds/2016/23 


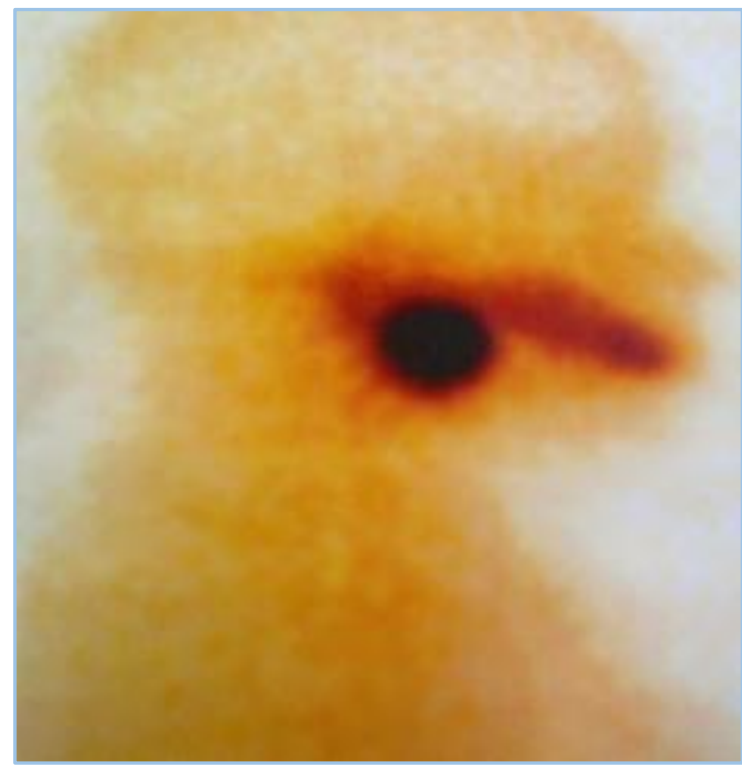

\section{Fig. 4a: Technetium uptake scan showing uptake only by lingual thyroid with no uptake at the site of normal thyroid}

\section{DISCUSSION}

Lingual thyroid is one of the commonest manifestations of ectopic thyroid tissue. Prevalence varies between 1:100000 to 1:300000 and its clinical incidence range from 1:4000 to 1:100000. True incidence of the same is probably underestimated. ${ }^{1}$ In literature approximately 400 cases of symptomatic patients have been reported.2 Ectopic thyroid tissue also found in geniohyoid, mylohyoid (Sublingual thyroid), above hyoid bone (Pre-laryngeal thyroid) rarely mediastinum of pericardial sac, heart, breast, pharynx, esophagus, trachea, lung, duodenum, mesentery of small intestine and adrenal gland.3-7 Dual ectopic thyroid is described. ${ }^{8}$ even with thyroid gland in a normal location. ${ }^{9}$ Thyroid gland is the first endocrine gland to develop during the $24^{\text {th }}$ day of gestation. Gland arises due to proliferation of endodermal epithelial cells on the medial surface of developing pharyngeal gut between first and second pharyngeal pouches.

It is present between tubercular in par and copula near foramen caecum. During the process of migration the gland is connected to the floor of pharyngeal gut by thyroglossal duct. Later it descents in front of the hyoid bone and laryngeal cartilage to lie in between $2^{\text {nd }}$ and $5^{\text {th }}$ tracheal rings. ${ }^{10}$ The thyroid gland then descends to meet the lateral ultimobranchial bodies; the fusion of these elements leads to the formation of the functional and mature thyroid gland by the third fetal month. ${ }^{11}$ The cause for thyroid dysgenesis is due to gene transcription factors T1TF-1, Foxe1 and PAX-8. Genetic mutation in these genes is responsible for abnormal descent of thyroid gland. Majority of ectopic thyroid tissue lies in the midline in the thyroglossal duct tract due to arrest of the migration. Ectopic thyroid tissue is the commonest cause of congenital hypothyroidism. Sometimes without ectopic thyroid tissue is present in $70 \%$ of people who may develop subclinical hypothyroidism. ${ }^{12}$ Malignant transformation of ectopic thyroid tissue is also observed in cases of lingual thyroid more in females at the ratio 3:1.

Commonly seen in females 3:1. Lingual thyroid may manifest at any age more commonly around puberty probably due to increased demand for thyroid hormone causing increase in circulating TSH resulting in growth of ectopic thyroid tissue.13 Symptoms are dysphagia, dysphonia, ulceration bleeding for the mouth. ${ }^{14}$ Malignant transformation and hypothyroidism are the common complications. Lingual thyroid will be seen as a pinkish mass behind the tongue and felt as a firm mass. USG neck shows presence or absence of gland in the neck. CT scan will show the presence of lingual thyroid in the neck. Technetium 99 scan reveals the radioactive uptake of thyroid tissue. Absence or presence of uptake of radioactive material in the neck indicates absence or presence of thyroid tissue in the neck.

\section{MANAGEMENT}

If lingual thyroid is the only functioning thyroid tissue conservative treatment is preferred. By giving regular oral dose of thyroxin which will reduce the size of the swelling and thereby reduce the symptoms. Surgery is indicated if it is producing symptoms of severe dysphagia, stridor, ulceration and bleeding and sudden increase in size indicating malignant transformation. The mode of excision is intraoral for small lingual thyroids by using preferably laser or radiofrequency which can seal off the bleeders.

Other approaches are transmandibular approach, lateral pharyngotomy approach and suprahyoid approach for large lingual thyroids. In lateral pharyngotomy the incision starts at the midline of submental region curving downwards towards the hyoid bone and extending up to the level of ear lobe. After sub-platysmal dissection the structures identified are carotid bifurcation, lingual artery, superior thyroid artery and hypoglossal nerve. In most of the cases of lingual thyroid, the carotid bifurcation is placed inferiorly at the level of thyroid cartilage and the superior thyroid vessels are small, hypo plastic or absent. The course of the superior thyroid artery is normal if present. But in majority of cases in lingual thyroid is supplied by branches of lingual artery or facial artery which can be ligated or coagulated.

The inferior thyroid artery is either hypo plastic or absent. Lateral pharyngotomy is done above the hyoid bone and inferior to hypoglossal nerve and the mass is visualized through the pharyngotomy opening and dissection is carried out. In transmandibular approach, incision is given at the level of mandible, suprahyoid dissection is carried out by lifting the suprahyoid muscles, the base of the tongue is pulled down and the lingual thyroid is brought out of the swelling and can further be excised.

\section{REFERENCES}

1. Saul JJ. Ectopic lingual thyroid. J Pathol 1970;102:239-43.

2. Gallo A, Leonetti F, Torri E, Maniciocco V, Simonelli M, DeVincentiis M. Ectopic lingual thyroid as unusual cause of severe dysphagia. Dysphagia 2001;16:220-3.

3. Di Benedetto V. Ectopic thyroid gland in the submandibular region simulating a thyroglossal duct cyst: a case report. J Pediatr Surg 1997;32:1745-6.

4. Kumar R, Sharma S, Marwah A, Moorthy D, Dhanwal D, Malhotra A. Ectopic goiter masquerading as submandibular gland swelling: a case report and review of the literature. Clin Nucl Med 2001;26:306-9.

5. Pollice L, Caruso G. Struma cordis. Ectopic thyroid goiter in the right ventricle. Arch Pthol Lab Med

1986;110:452-3. 
6. Porqueddu M, Antona C, Polvani G, Cavoretto D, Pompilio G, Gianilli L, et al. Ectopic thyroid tissue in the ventricular outflow tract: embryologic implications. Cardiology 1995;86:524-6.

7. Ferlito A, Giarelli L, Silvestri F. Intratracheal Thyroid. J Laryngol Otol 1988;102:95-6.

8. Hazarika P, Siddiqui SA, Pujary K, Sha P, Nayak, Dr. Balakrishnan R. Dual ectopic thyroid: a report of two cases. J Laryngol Otol 1998;112:393-5.

9. Huang TS, Chen HY. Dual thyroid ectopia with a normally located pretracheal thyroid gland: case report and literature review. Head Neck 2007;29:885-8.
10. Ulug T, Ulubil SA, Alagol F. Dual ectopic thyroid: report of a case. J Laryngol Otol 2003;117-574-6.

11. Chanin LR, Greenberg LM. Pediatric upper airway construction due to ectopic thyroid: classification and case reports. Laryngoscope 1988;98:422-7.

12. Yoon JS, Won KC, Cho IH, et al. Clinical characteristics of ectopic thyroid in Korea. Thyroid 2007;17:111721.Steinwald OP Jr, Muehrcke RC, Economou SG. Surgical correction of complete lingual ectopia of the thyroid gland. Surg Clin North Am 1970;50:1177-86.

13. Halfidh MA, Sheahan P, Khan NA, et al. Role of Co2 laser in the management of obstructive ectopic lingual thyroids. J Laryngol Otol 2004;118:807-9. 